\title{
Mourning and longing: Media studies learning to let go of liberal democracy
}

European Journal of Communication 2015, Vol. 30(5) 554-570

(C) The Author(s) 2015

Reprints and permissions: sagepub.co.uk/journalsPermissions.nav DOI: I0.1 I77/0267323 II5597854 ejc.sagepub.com

@SAGE

\author{
Natalie Fenton \\ Goldsmiths, University of London, UK
}

\section{Gavan Titley}

Maynooth University, Ireland

\begin{abstract}
In her essay 'Neoliberalism and the end of liberal democracy', Wendy Brown suggests that critical political theory needs to 'mourn liberal democracy' in order to develop a transformative vision of 'the good'. The problem, as Brown outlines it, is not only that - to varying extents and in different scales across democratic states - market rationality has hollowed out representative structures and processes and organizes social life but also that 'basic principles and institutions of democracy are becoming nothing other than ideological shells' that nevertheless legitimate neoliberal governmentality. Brown's concept of mourning has implications for Media Studies' constitutive focus on publicness and political participation within the democratic nation-state. This article considers Brown's critique in relation to the tendency in Media Studies to admit the unachievable idealism of certain ideas - particularly in relation to the public sphere and pluralism - while continuing to use them as guiding normative standards and values. The article questions how such normative ideals can provide guidance where not only the political and institutional imaginary that underpins them has changed, perhaps irrevocably, but where the continued flagging of these ideas may be implicated in the kind of ideological camouflage Brown identifies.
\end{abstract}

\section{Keywords}

Capitalism, liberal democracy, neoliberalism, pluralism, public sphere

\section{Introduction: The invitation to mourn}

In recent times, there has been no shortage of instances where media institutions and communication practices have become both concrete sites and compelling symbols of

\section{Corresponding author:}

Natalie Fenton, Goldsmiths, University of London, Lewisham Way, London, SEI4 6NW, UK.

Email:n.fenton@gold.ac.uk 
systemic political crisis and democratic struggle. The movement for media reform precipitated by phone hacking in the United Kingdom; opposition to oligarchic media concentration in Italy, Hungary, Australia and Canada, to mention but a few key sites; or the intensive conflicts of state actors with deterritorialized networks of informational activism - from Wikileaks to the ongoing case of Edward Snowden, Glen Greenwald and the National Security Agency (NSA) (see Harding, 2014). These contestations have ensured that public debate on whether or not - and in what forms and ways - the media enhance or frustrate the practice of democracy endures and occasionally rages.

As media scholars we tend to focus on and problematize the media side of this debate. Media, as Dahlgren (2009) writes, '.. are a prerequisite - although by no means a guarantee - for shaping the democratic character of society' (p. 2). By examining issues such as media ownership and pluralism, freedom of the press and the emergent digital possibilities for citizens to claim increased communicative autonomy, media studies scholarship has long sought to specify the institutional arrangements, public processes, civic practices and political-economic conditions that give substance to media's role as a democratic prerequisite. However, less attention has been paid to the 'democratic character of society', and, more specifically, to the implications of significant shifts in the distribution of power within representative democracies for established ways of considering media's democratic functions. This article argues that central concepts dedicated to grounding 'media as democratic prerequisite' need to account for how the democratic character of societies is not only 'not guaranteed' under conditions where the agency of representative democratic institutions has been diminished (Crouch, 2004, 2010) but where, under conditions of neoliberal capture, democracies, as Gilbert (2013) argues, are riven by a 'fundamental democratic crisis ... a crisis in the capacity for collective decisions to be taken and upheld' (p. 3).

The cumulative evidence of fissures and failures in the project of representative democracy has consequences for the theoretical constitution of liberal democracy in media studies, a dominant constitutive framework that all too frequently organizes discussions of democracy through concepts such as the public sphere, pluralism and communicative freedom (albeit not only through these concepts). It is commonplace to be told that a free and fair media are the lifeblood of democracy - that the free flow of mediated information runs through the very veins of the body politic of democratic states. In this form of media-centrism, where media are placed at the heart of all systems, it is all too easy to claim that enhancing democracy primarily or centrally depends on a media solution - more plurality, less concentration, better representation.

Of course, all of these concerns are of vital importance, yet when written predominantly from the 'media side' of the equation, they tend to distract our attention away from the broader, shifting context of which they are but a part. The debate we wish to initiate inquires as to how we may need to re-conceptualize and re-work media studies paradigms that retain a normative and often somewhat teleological relationship to particular - ideal - democratic forms, even as these forms mutate (McNally, 2010). In short, we aim to question the status of guiding ideas saturated in assumptions about how deliberation, representation and democratic politics may work, as representative democracy and the organization and distribution of power shift in ways not registered in these canonical ideas. 
In what follows, we pursue this argument by situating these questions in the insistent political context of the Eurozone crisis and broader global economic instability of the last 5 years. During this period, we have seen the publication of some significant assessments of the current political-economic crisis on democratic systems (Crouch, 2011; Streeck, 2011). In turn, this literature positions the crisis as a critical disjuncture in a deeper and multi-faceted crisis of representative democratic systems, long regarded as weakened by the competitive imperatives of economic globalization and the declining counter-power of organized labour (Crouch, 2004); the shrinking range and register of party political action and conceivable, alternative political projects and policy interventions in postmodern societies (Gilbert, 2013; Mair, 2013); the retraction of the state from the provision of public goods and infrastructure (McNally, 2010; Seymour, 2014; Tyler, 2013); the increased power of corporations and transnational financial agencies over public priorities (Mair, 2013) as well as the elite choreography of 'adversarial' politics in democracies that 'speak without listening' (Dean, 2009). The scale of this disjuncture demands responsive assessments of Media Studies' democratic imagination, particularly if, as Schäffer and Streeck (2013) contend, '... it is impossible to imagine what the politics of democracy-cum-austerity will be like - in (as yet still) rich democratic-capitalist countries co-governed by global capital markets - as there are no valid historical precedents' (p. 419loc).

\section{The reasons to mourn}

For the purposes of our response, we draw centrally on Wendy Brown's (2005) essay 'Neoliberalism and the End of Liberal Democracy', as we wish to extend her invitation to Political Philosophy to 'mourn' liberal democracy to the discipline of Media Studies. Brown's essay is in part an assessment of how the emergency measures introduced as part of the 'war on terror' intensified dimensions of neoliberal governmentality; however, the general thrust of Brown's arguments concerning the erosion of political citizenship in a system of 'control without responsibility' is pertinent. Therefore, while situated in the US context, it provides a useful critical register for approaching the political and analytical challenges for thinking and writing about democracy under conditions of neoliberal capture.

For Brown (2004), neoliberal governmentality amounts to a new political formation that erodes the relative autonomy of democratic and state institutions from the market and that entails the '... erosion of oppositional political, moral, or subjective claims located outside capitalist rationality yet inside liberal democratic society, that is, the erosion of institutions, venues and values organized by nonmarket rationalities in democracies' (p. 45). Liberal democracy, over and above the often fundamental reservations of established left critiques, is recognized to have provided a modest ethical and pragmatic buffer between citizens and the 'free hand' of the market; thus, 'while liberal democracy encodes, reflects and legitimates capitalist social relations, it simultaneously resists counters and tempers them' (Brown, 2004: 46). The hegemonic construction of neoliberal formations (Gilbert, 2013) has resulted in a process of capture, where, Brown (2004) contends, 'liberal democracy' no longer signifies a set of independent institutions, civic 
practices and the 'principle of popular sovereignty' but rather 'indicates only a state and subjects organized by market rationality' (p. 48).

In perhaps the only Media Studies critique to engage with Brown's essay, Daniel Hallin rightly suggests that the theoretical survey of her argument could be read as symptomatic of a historical shift away from a 'golden age' deemed healthier than today's 'unprecedented degree of passivity and political complacency'. Hallin (2009) questions whether such an age could ever be delineated in the socio-political history of the United States, before going on to dismiss every decade since the Second World War in support of his argument (p. 52). However vulnerable Brown is on precise questions of periodization - if not historicization - she is very clear on the extent of her claim; 'what is unprecedented about this time is the extent to which basic principles and institutions of democracy are becoming nothing other than ideological shells concealing their opposite', that is, where non-market moralities have been displaced by a 'thoroughgoing market rationality'. What we are then left with under neoliberalism are the 'residues of old-fashioned democracy inside the legitimation project of neoliberalism', one that 'conducts and legitimates itself on different grounds from liberal democracy even as it does not immediately divest itself of the name' (Brown, 2004: 56).

It is symptomatic of this transition, Brown argues, that critics attuned to representative democracy's shortcomings are compelled to defend liberal principles even as they are being eroded. Consequently, pointing out the ways in which questions of freedom and democratic principle are impugned or hypocritically transgressed is of little effect because they have come to mean something else, and 'political reasons and reasoning that exceed or precede neoliberal criteria have ceased to matter much' (Brown, 2004: 59). Two recent examples briefly illustrate the point. When a US graduate student analysed methodological flaws in the data in Carmen Reinhart and Kenneth Rogoff's (2010) paper 'Growth in a Time of Debt' - a paper widely proclaimed by technocratic policy elites to justify significant cuts in public spending this revelation was treated as rational proof of 'the case for austerity being undermined' (see Krugman, 2013). However, if austerity is understood as a political project (Schäffer and Streeck, 2013) required to restore 'confidence' in financial capitalism by neoliberalism in crisis, the assumption that reasoned and rational proof in the public sphere is of deliberative democratic value ceases to be credible. Or alternatively, we can look to the notion of the 'freedom of the press' in the United Kingdom: a noble ideal based on an independent journalism of integrity that has been re-appropriated by the libertarian right and used to fight against the establishment of an independent and effective democratic system of press accountability. In the process, 'freedom' has been transmuted into the freedom of powerful media corporations to say and do whatever they like in pursuit of profit, and in the name of 'the people'. The press in the United Kingdom have an awful lot of freedom, but not of the sort that necessarily defends or deepens democracy.

The challenge for critical thought is negotiating how neoliberal governmentality voids liberal democracy of substance, but takes shape in and acts through democratic discourses of freedom, participation, choice, empowerment and pluralism. The question, for Brown, is how to engage with a democratic vocabulary that also acts as neoliberalism's cloak. It is the need to evade terms and discourses saturated in market 
rationality that compels Brown to invite political philosophy and activists to 'mourn' liberal democracy and to develop counter-rationalities for human flourishing and alternative visions of a good political life. It strikes us that Brown's argument about the profound re-articulation of democratic discourses is of consequence for Media Studies paradigms that, while fully capable of identifying the gaps between democratic principles and practices, end up accepting and prioritizing democracy in abstract forms that do not fully take account of these modes of capture and hollowing out forms that too frequently masquerade as liberal democracy through donning some of its easily recognizable accoutrements - the technicolour coat of pluralism, the fancy pants of freedom - but hide a body politic beneath that has morphed into something rather different: neoliberal democracy. In other words, unless we interrogate liberal democracy - and address its histories as a political project and its transformations within political systems - as a condition of theorizing the role of media therein, we risk colluding with the neoliberal capture of democracy and of its increasing demise as theorized by Brown.

In response to this risk, and by drawing on Brown's analysis of how traces, vocabularies and hopes derived from 'old-fashioned democracy' are integral to neoliberal legitimation, we wish to assess how a project of critical mourning would transform key Media Studies concepts hewn from an era of representative democracy that is undergoing profound transformation. In the next section, we inquire as to whether translating Brown's insights to the context of the Eurozone crisis may focus our mourning on one of Media Studies' most influential examples of democratic vocabulary.

\section{Crisis and mourning in the conjuncture}

\section{The Public Sphere after the end of deliberation?}

When it comes to framing the relationship between the media and democracy, the dominant normative framework, critical touchstone and ritual allusion are the Habermasian concept of the public sphere (Habermas, 1989[1962]). Given the scale of this engagement, an overview is clearly beyond the scope of this article, and therefore, we will engage primarily with the work recently assembled by Peter Lunt and Sonia Livingstone (2013) in detailing what they term Media Studies' 'fascination' with the concept. Habermas' historical documentation of a bourgeois public sphere of debate and the deliberative emergence of 'public opinion' as a form of political action, and his account of its structural transformation into a 'manipulated public sphere', is well-known. Equally well referenced are criticisms of its inattention to power relations of gender, class and racializing structures, and the need to recognize the inter-play of multiple - and counter - public spheres for debate and deliberation to be as broad as possible (Downey and Fenton, 2006; Mouffe, 2005).

Lunt and Livingstone's account examines the impact of these critiques, first by emphasizing the timing of the translation of Habermas' book into English, intersecting as it did with a normative retrenchment in the importance of public (media) institutions under conditions of Thatcherite assault and with the burgeoning influence of Foucauldian ideas on the dispersed and multiple workings and effects of power: 
So it is with ambivalence that media scholars have continued to work with the concept of the public sphere. Many adopt the pragmatic view that the concept establishes a good starting point, a framework against which to test one's ideas and assumptions. But his account of the media was surely better suited to mass media in the context of post-war social reconstruction and Cold War politics of America and Europe than to the complex, multimedia environments that we now inhabit. (Lunt and Livingstone, 2013: 90)

Consequently, re-articulating the centrality of discursive processes of deliberation to a normative vision of the public sphere required diluting the imaginary of a sovereign public in a reckoning with socio-cultural diversity, networked transnationalism and political subjectivities animated by expansive ideas of what constitutes the political (McKee, 2005). In Lunt and Livingstone's detailed reading, Habermas' reconstruction of the idea of the public sphere in an ongoing commitment to normative democratic theory has involved recognizing the complexity of 'modern pluralistic liberal democracies' and understanding deliberation less as the processual horizon of a sovereign public but rather as the outcome of contestation in and across multiple, dispersed 'forms and sites of deliberation' (Lunt and Livingstone, 2013: 92). On this basis, Habermas envisions institutions acting in the public sphere and supporting deliberation by appealing to civic virtue and active public participation, adopting a 'progressive media ethics' that negotiates difference with a 'broader public interest', by media institutions 'translating the key issues and concerns of the public into a language that is intelligible to the political administrative context' and by actively engaging the public in the production of news and current affairs (Lunt and Livingstone, 2013: 94-95).

Lunt and Livingstone's (2013) review ends by posing a series of questions to media studies scholars as to whether this normative vision is valuable, sufficient or sustainable. We will discuss one of the responses to their questions subsequently, but for now we wish to register how these questions reflect Brown's critical concern with assessing the import of concepts shaped under receding historical conditions, while limiting this assessment to its relevance to media institutions and communicative action. We suggest that a fourth question is necessary: what is the status of a normative democratic theory of communication under conditions of 'post-democracy', characterized not only by communicative expansion but also by reduced political influence and democratic agency in relation to the economy and social policy? In other words, if we focus on enhancing the process and quality of deliberation, but deliberation has little or no impact on the 'political administrative complex', does the Public Sphere not enter the lexicon noted by Brown, of liberal democratic ideas hollowed out by neoliberal governmentality?

To explore this, we wish to further embed our discussion of a crisis of representative democracy in terms of the recent Eurozone and global financial crisis. Of the current media institutions foregrounded as symbols and sites of this crisis, the summary closure of the Greek public service broadcaster ERT most clearly refracts the scale of democratic subversion enacted by and through the Eurozone crisis. As the philosopher Costas Douzinas noted, the sudden disappearance of the ERT signal viscerally recalled the era of military dictatorship, but was effected on the back of a presidential decree, a once extraordinary measure that has become a commonplace instrument for implementing Troikaderived decisions without parliamentary approval. While the closure was countered by an 
occupation of journalists and their supporters - and the Athens-based Press Project rapidly mobilized an online, samizdat broadcasting network - for Douzinas, the targeting of the public service broadcaster is emblematic of what he terms the intensifying 'destruction of democracy' in Greece, a process that has received less attention, in his estimation, than the 'well-documented economic and humanitarian crisis' (Douzinas, 2013).

In Greece's near but frequently distant neighbour, at the same time the close relationship between media patrons and the ruling AK party (Adalet ve Kalkınma Partisi) ensured that the major television channels acted as ostriches and broadcast only penguins as Istanbul, and subsequently other cities across Turkey, rose up in mass protest against planning corruption and the subsequent repression of democratic assemblies (Öktem, 2013). What is of interest here is that both the closure of the Greek television station and the repression in Turkey were justified in overtly democratic terms. According to the Greek Prime Minister (PM) Antonis Samaras, ERT - which was unplugged just as the Troika completed their latest inspection of 'cost-cutting' measures - had become a symbol of a 'lack of transparency' that eroded public trust and therefore required, in that most malleable of neoliberal euphemisms, 'reform'. The Turkish PM, Recep Tayyip Erdoýan, has consistently pointed to his parliamentary majority and the inability of the protestors to 'impose their will at the ballot box' as evidence of the antidemocratic nature of the protests.

In one sense, of course, these strategic narratives are unremarkable. Much as nobody is a racist, almost everybody is a democrat, and Jean-Luc Nancy's (2009) observation that 'democracy' is incapable of 'serving any heuristic purpose' where it is invested with such elastic, positive charge has some validity. Furthermore, appeals to the formal legitimation of the electoral process when faced with emergent, popular mobilization are a historical constant of bourgeois democracy shaped, as Raymond Williams (1982) argued in 'Democracy and Parliament', by 'the coexistence of political representation and participation with an economic system which admits no such rights, procedures or claims' (p. 19). Yet, they also reflect Brown's thesis as to formations that undermine democracy even as they invoke its name. Crouch has termed this 'post-democracy', a state where 'the forms of democracy remain fully in place', yet 'politics and government are increasingly slipping back into the control of privileged elites in the manner characteristic of pre-democratic times' (Brown, 2004: 6).

Contemporary assessments of the Eurocrisis suggest that the coercive nationalization of a systemic capitalist crisis has acutely rendered the scale of post-democratic transition. The extent to which one agrees (or disagrees) with Douzinas' diagnosis, or De Sousa Santos' (2012) description of the crisis as furthering the 'expropriation of democracy', may depend in large part on one's geographical as well as political positioning. Nevertheless, several wide-ranging studies and polemics note that much as the threat of global financial meltdown in 2008 was falsely assumed to empirically undermine neoliberal rationality, it was also fleetingly regarded, given its acute exposure of unaccountable networks of power, as an opportunity for democratic renewal (Graeber, 2011).

The putatively corrective imposition of 'austerity' in Troika-administered and other countries in Europe has, however, manifested the forlorn nature of this hope. Two strands of critical response have been developed in response. In the first, the futility of the policies imposed, and their negative democratic consequences are emphasized. In a recent 
study, Blyth describes austerity's faith in cutting a return path to growth as the 'zombie economics' ${ }^{1}$ that disguises what is a 'banking crisis first and a sovereign debt crisis second'. He moves beyond the data to spell out the political consequences:

Austerity, then, is a dangerous idea because it ignores the externalities it generates, the impact of one person's choices on another person's choices, especially for societies with highly skewed income distributions. The decisions of those at the top on taxes, spending, and investment prior to 2008 created a giant liability in the form of a financial crisis and too big to fail and bail financial institutions that they expect everyone further down the income distribution to pay for ... in sum, when those at the bottom are expected to pay disproportionately for a problem created by those at the top, and when those at the top actively eschew any responsibility for that problem by blaming the state for their mistakes, not only will squeezing the bottom not produce enough revenue to fix things, it will produce an even more polarized and politicized society in which the conditions for a sustainable politics of dealing with more debt and less growth are undermined. Populism, nationalism and calls for the return of 'God and gold' in equal doses are what unequal austerity generates, and no one, not even those at the top, benefits. (Blyth, 2013: 17-18)

For other analysts, however, the imposition of austerity was less a result of zombie activity than parasitic recuperation. McNally (2010) frames austerity as a 'neoliberal mutation', predicated on the rapid discursive and political shift away from the systemic weaknesses of finance capitalism to the ideological 'necessity' of slashing state investment and spending, that furthers a long-term project to transform the social function of the modern state. Scholars are understandably cautious of claims of historical rupture; however, arguments such as McNally's and that recently proposed by Streeck must be taken seriously politically, and also for the pointed challenge they pose to critical research and Media Studies' democratically derived conceptual repertoire.

Social science, Streeck (2011) argues, must, at a contemporary minimum, 'point out the drama of democratic states being turned into debt-collecting agencies on behalf of a global oligarchy of investors'. In this, and a subsequent (Streeck, 2012) piece entitled 'Markets and Peoples', Streeck theorizes the financial crisis as a product of the fundamental contradictions of 'post-war democratic capitalism', whereby states have been structurally required to balance the needs of two sovereigns, 'their people, below, and the international "markets" above'. Since 2008, he argues, 'the dialectic of democracy and capitalism has been unfolding at breathtaking speed'. Specific programmes of bailout conditionalities and the wider drive to restore investor confidence through the project of state retraction euphemized as 'austerity' suggest, according to Streeck (2011), that

... more than ever, economic power seems today to have become political power, while citizens appear to be almost entirely stripped of their democratic defences and their capacity to impress upon the political economy interests and demands that are incommensurable with those of capital owners. (p. 29)

What Streeck is proposing then is that the Eurozone crisis marks a disjunctive moment in a longer process, described by Gilbert (2013) as a 'much deeper crisis of political democracy which has been under way for 30 to 40 years - almost as long as mass 
democracy has lasted before the crisis struck' (p. 4). The capacity of financial markets to dictate economic and social policy and, through a variety of performative technologies and mediating institutions, to discipline national governments has rendered the forms of hollowing and capture discussed by Brown manifest and resulted, inter alia, in political movements that find unity in their diversity through a marked rejection of the political establishment and hostage institutions and a demand for 'real democracy now'.

The spaces and processes of Europe's anti-austerity movements have been marked by commitments to deliberation and certainly map onto a key trajectory of public sphere theory renewal, which argues for grounding '... deliberative democracy in a strong critical theory of communicative action, and to re-emphasize oppositional civil society and public spheres as sources of democratic critique and renewal' (Dryzek, 2000: 3). Nevertheless, developments in the Eurozone invite us to re-think the relationship between communicative action and democratic process when the 'resolution' of the Eurozone crisis in the periphery has required the imposition of settlements immune to, and deliberately inured from, democratic influence (Lapavitsas, 2012).

Given this, it is instructive to return to one of the responses to Lunt and Livingstone's questions as to the continuing relevance of the Public Sphere in Rasmussen's (2013) article on 'Internet-based media, Europe and the political public sphere'. Rasmussen is interested in the capacity and possibility for networked media to contribute to a 'critical public sphere' and also situates his analysis squarely in the context of the Eurocrisis. While positing the 'dramatic differentiation of the public sphere' wrought by interactive, participative digital media as a 'democratic problem', Rasmussen (2013) argues for retaining the idea of the public sphere in the singular, as it 'makes it easier to see the essential role of the public sphere in a deliberative democracy' (p. 98). His normative framework not only posits the possibility of deliberative democracy but requires it in order that 'legitimacy and stability for the political system' can be ensured in a complex, differentiated public sphere (Rasmussen, 2013).

Rasmussen (2013) situates this problematic in an analysis of the Eurocrisis, where 'the European political project seems to stand at a crossroads' (p. 101). He surveys reasons for the weak emergence of a 'European public sphere' - 'Although there are overlapping agendas, international circulation of some quality newspapers, coverage of international events and international NGOs, a contemporary European public sphere can only be imagined in a soft, weak-tie sense' (Rasmussen, 2013: 102), with consequences for 'European public opinion' (see also Fossum and Schlesinger, 2007). It is not ultimately clear how Rasmussen's desire for a 'robust European public sphere in the future' relates to possible resolutions of the Eurozone crisis, but the suggestion is that a common and integrated media would contribute to the formation of a 'public will' that, while admitting of conflict and disagreement, would reinvigorate commitment to the troubled European project (Rasmussen, 2013: 102-103).

What we wish to draw attention to is that while this assessment is written under the sign of the Eurozone crisis, the political economy, material consequences and political ruptures wrought by this crisis are entirely absent from Rasmussen's discussion. The internal colonialism of the Troika settlements, the Darwinian logic of 'Triple A' hegemony, the documented coercion brought to bear on elected governments, the police brutality visited on mass protests, the rise of far-right street movements and anti-immigrant 
and anti-European Union (EU) populist parties, the catastrophic levels of youth and general unemployment and falling living standards, none of these is regarded as having impacted the credibility of the European project. Rather, attention is fully paid to the 'media side' of democratic development and the requirement of an 'integrated will formation in Europe' (Rasmussen, 2013), even as the European institutions openly engage in side-stepping already limited democratic accountability for the forms of 'fiscal consolidation' required to rescue the system of financial capitalism. We recognize, of course, that the article is explicitly written through the lens of media analysis, yet we return to the argument made in introduction as to the limitation imposed solely by engaging with the 'media side of the equation'. As Streeck (2011) points out, social science must acknowledge the 'drama' it is situated within. What kind of public sphere, we wonder, does debtocracy require?

It is not the absence of deliberation, or conduits for deliberation, that characterize the Eurozone crisis, but rather the unresponsiveness of representative democratic structures to popular opposition to the imposition of austerity. For Streeck, this intensified crisis of democratic legitimation is marked by a transition from 'people whisperers' to 'capital whisperers', and this striking metaphor captures precisely the problem for Public Sphere theory that does not reflect on whether the normative cultivation of communicative action has agency in a conjuncture where, as Streeck (2012) implies, the attention of governance is to the conditions required to stimulate 'market confidence' rather than responding to 'public opinion', never mind popular struggle.

What this example indicates more generally, we contend, is that the implications of this unravelling dialectic of democracy and capitalism for those media studies paradigms generated, and heavily invested in the historical heyday of representative democracy, remain to be examined.

\section{Pluralism and communicative freedom}

A key critique of the Public Sphere has been its focus on the nation-state and the contours of the imagined public. Our analysis of the Eurozone crisis suggests that the role of the nation-state - as an enforcing mechanism if nothing else - cannot be underestimated. However, it is clear that theorizations of networked media and transnational formation have been more attuned to the shifting distribution of power as played out in the global crisis. This is why another key concept in Media Studies, pluralism (of media forms and content), has been increasingly explored in relation to the interactive and participatory possibilities of the internet and digital media and reinforced as a democratic goal in a networked era. In such debates, digital citizenship and civic responsibility are seen as being facilitated by new technology, where new publics are realized through newly mediated pluralistic public spheres that lead to enhanced participation and thus better democracy. Scholars such as Castells (2009) and Benkler (2006), for example, advance rather different versions of an ultimately similar proposition wherein the promise of plurality that the internet presents is foregrounded as the means to communicative and democratic freedom.

In Benkler's (2006) analysis, the internet has the potential to change the practice of democracy radically because of its participatory and interactive attributes that engender 
a more pluralistic and civic engagement. Increased capacities to access the internet and to produce and disseminate media content within expanding and thickening networks are argued to transform the relations of producer and audience, and enable all citizens to alter their relationship to the public sphere, to become creators and primary subjects engaged in social production. In other words, citizens gain communicative freedom, and the more they gain, the more the public sphere expands; in Benkler's (2006) words,

the high capital costs that were a prerequisite to gathering, working, and communicating information, knowledge, and culture have now been widely distributed in the society ... [such that] ... we have an opportunity to change the way we create and exchange information, knowledge and culture. (p. 473)

The consequence of this ever-expanding networked sociality is claimed as enhanced democratization, where the flow of information and possibilities for participation radically expand access to media power and enhance information pluralism that in turn supports political pluralism and the means to communicative freedom.

Similarly, Castells (2009) argues that social movements that engage in oppositional politics - 'the process aiming at political change (institutional change) in discontinuity with the logic embedded in political institutions' (p. 300) - are now able to enter public space from multiple sources and positions raising the possibility for major social and political change: 'could it be that the technological and organisational transformation of the network society provides the material and cultural basis for the anarchist utopia of networked self-management to become a social practice?' (p. 346). In his argument, the multiplicity of prospects for intervention and inventiveness coming from a myriad of social nodes combine to create a new symbolic counter-force that can change social practice. By using both horizontal communication networks and mainstream media to convey their images and messages, social movements increase their chances of enacting social and political change - 'even if they start from a subordinate position in institutional power, financial resources, or symbolic legitimacy' (Castells, 2009: 302). Once again, pluralism and communicative freedom work in tandem and in ever-expanding circles; the more freedom one has, the more plurality is produced, and the more plurality there is, the more freedom one has.

As Castells acknowledges, the apparently limitless plurality on offer in an Internet age is bounded, offset and challenged by other socio-economic and political factors. Concern as to the shifting yet resistant nature of 'digital divides' is not restricted to access to the internet and the huge gaps prevalent between the global North and South; they also refer to online activity within developed nations and to traditional divides between the well educated middle class - who dominate public discourse online as well as offline - and those on the peripheries or excluded altogether (Hindman, 2008; Tyler, 2013). Here, we would argue, new paradigms of pluralism can only be evaluated when integrated into an assessment of intersecting forms of social inequalities (and their dramatic consequences for representative democratic systems; see Dorling, 2011).

Decline in voter turnout, for example, is a markedly general trend across European states (Mair, 2006). As Schäffer and Streeck (2013) note, electoral turnout has further diminished during the Eurozone crisis, and notably so for the socio-economically 
excluded (p. loc 207-285). The United Kingdom, for example, went from 4\% difference in turnout between high and low earners in the 1987 general election to $23 \%$ difference by 2010, with the voting gap between the young and old stretched even wider with a $32 \%$ difference in turnout between the over- 65 s and under- $24 \mathrm{~s}$. When you compound this by comparing the voting habits of the old rich with the young poor, the results become what Lodge et al. (2013) call 'toxic'. Only a third of under-35s earning $£ 10,000$ or less bothered to vote in 2010 , compared with almost $80 \%$ of over- 55 s earning $£ 40,000$ or more.

Add this to the stark fact that the result of the UK 2010 election was decided by only $1.6 \%$ of the electorate (Lodge and Gottfried, 2011), and the pluralism vested in the communicative freedom on offer in the digital age and the pluralism materialized in representative democratic processes diverge starkly. The counter-argument that young people are not less interested in politics but rather have rejected traditional electoral systems in favour of non-bureaucratized, decentred protest politics that speak better to their concerns and experience of a networked society certainly has purchase (Loader, 2007). However, we are concerned here with the displacement of democratic energy fully to the potentials of the network, as this elides the systematic exclusions characterizing democratic systems, and the material realities of poverty and inequality that weigh down the imagined subjects of communicative freedom.

It follows from this that attempts to characterize the expansion of the public sphere through communication must, if the normative desire is democratic, relate their account to the concerted contemporary assault on the institutions and goods of the public realm. For example, the current UK government's first spending review in 2010 delivered average voters a loss of $12 \%$ - $£ 1850$ - while average non-voters lost $20 \%$, or $£ 2135$ (Lodge et al., 2013). In a brutal move that eliminated the educational prospects of the young disadvantaged, the education maintenance allowance was scrapped, and supports such as the child trust fund, child benefit, tax credits and cheap travel for the young were reduced. Meanwhile, through the reintroduction of tuition fees, an average $£ 40,000$ of debt was piled on to the backs of students, further eroding the 'pluralism' of our university communities (Lodge et al., 2013).

Our intention here is not reductionist. Rather, it is to call for a critical examination of the democratic potential of new distributions of communicative power adequate to the materiality of how increasing inequalities in societies lead to vastly impoverished democracies. As Wilkinson and Pickett (2009) argue - and provide systematic supporting evidence for - '.. the health of our democracies, our societies and their people is truly dependent on equality' (p. 298). Yet, plurality in terms of access and therefore the ability to take advantage of plurality in terms of voice and content are, it would seem, increasingly reserved for the privileged.

As Nancy Fraser (1995) notes, inequality is not just socio-economic but also concerns recognition. Taylor (1994) also notes that

Non-recognition or misrecognition ... can be a form of oppression, imprisoning someone in a false, distorted, reduced mode of being. Beyond simple lack of respect, it can inflict a grievous wound, saddling people with crippling self-hatred. Due recognition is not just a courtesy but a vital human need. (p. 25) 
Non-recognition and misrecognition in the mainstream media are, as Nancy Fraser notes, 'cultural injustices' that impact our political and social selves. In the same way, the notion of democracy is connected both to the mediation of information and to people as thinking, voting and acting publics. Michael Förster, author of the Organisation for Economic Co-operation and Development's (OECD) report Divided We Stand, has noted that in the United Kingdom $65 \%$ of people say that inequality is too high yet at the same time they vastly underestimate its extent. Poverty and the poor, suffer constant non-recognition in the mass media (Golding and Middleton, 1982; Redden, 2011), and this has deleterious political consequence. Indeed, as Tyler (2013) has recently argued, increased inequality has been accompanied by the 'heightened stigmatization' in political discourse of 'disposable' populations, to the extent that 'stigmatization operates as a form of governance which legitimizes the reproduction and entrenchment of inequalities and injustices' (p. 231loc; italics in original). Undoubtedly, these processes of stigmatization are contested and unsettled in multiple ways online. However, this is not the same as contending that pluralism online has provided a prevailing 'outside' to neoliberal rationality.

Accounts that rely upon the elision of pluralism - both in terms of access and in terms of multiplicity of content and content creation - and communicative freedom as democratic enrichment depend on an implicit assumption about the consequential relations between pluralism, networked communication, participation and politics. Introducing inequality - economic, cultural, social and technological inequality - to any debate relating to plurality and freedom is critical. It follows from this that accounts that elide pluralism with communicative freedom must account more fully for the concept of power that they operate with. Castells (2009), for example, in Communication Power devotes considerable time to analysing corporate power in an online context. He argues that 'the media are not the holders of power, but they constitute by and large the space where power is decided' (Castells, 2009: 242). In other words, as Freedman (2014) points out, media institutions act as hosts of power struggles and invite the real power-holders of international finance, politics and business onto their platforms. The media thereby 'constitute the space where power relationships are decided between competing political and social actors' (Castells, 2009: 194). Therefore, if this space is expanded, regardless of whether or not this results in greater concentration of media ownership, or further commodification of user-data online, competition between actors will be increased and power dispersed, generating 'media counter-power' (Castells, 2009). This understanding of pluralism may not herald market forces as a guarantor of freedom, but it nonetheless claims that the internet, regardless of its ever-increasing capture by free market media, will empower sovereign audiences through the creative autonomy bestowed upon them. However, while recognizing that power always exists in multiple forms and that it would be grossly misleading to claim that the corporate purveyors of capitalism prevent counter-power from emerging, it remains crucial to also recognize that different types of power have differential influence.

It is instructive to return to Gramsci's theory of hegemony here and his attempt to explain how and why we consent to established power relations. He describes hegemony as giving the hegemonic group 'directive' authority (Gramsci, 1971: 408). So although hegemony may always be contingent, ever changing and uncertain, it still 
steers the general direction of travel to which we must consent 'either actively or passively' (Gramsci, 1971: 12) for hegemony to be effective. In other words, we do not need to enthusiastically endorse a particular direction of travel for consent to be enacted. In fact, we can actively refuse to endorse the many facets of neoliberalism that underpin the brutal inequalities outlined above while passively consenting to them. In doing so, we get used to the general direction of travel that enables us to go along with the view that simple pluralism correlates with communicative freedom and will deliver better democracy, thereby disabling any effective opposition to the established hegemony from emerging.

\section{Conclusion}

The above discussion is not to deny the enormous benefits of the creative and political activities that occur online and that are greatly facilitated by digital media. Yet the tendency to elide pluralism with communicative freedom, and to posit the linear correlation of access-communicative freedom/pluralism-political participation, relegates the influence of 'power over' in an over-enthusiastic embrace of the 'power to'. This runs the risk of reducing power to an individual resource that is purely relational and behavioural and one that will always over-emphasize technology to the detriment of social, political and economic context. In its poorest manifestation, this descends into 'clicktivism', signing online petitions, writing dissenting blogs, sending political tweets that, as Dean (2009) has argued, are fully recuperable in a context where

rhetorics of access, participation and democracy work ideologically to secure the technological infrastructure of neoliberalism, an invidious and predatory politico-economic project that concentrates assets and power in the hands of the very, very rich, devastating the planet and destroying the lives of billions of people. (p. 23)

In its richest manifestation, it provides us with a complex picture of the instability of power relations, engendered through expanded communicative freedom and working in a non-stratified and diffuse manner. Here, we do not contest the need to account for a Foucauldian micropolitics nor those Deleuzian rhizomatic politics rooted in the knowledge that every person is a plurality, every group a multitude of differences, all operating at varying levels in a complexity of matrices at any one time. It is also easy to see how this strikes a chord with a networked politics of new social movements built on recognition of individual difference but common cause, however, loosely articulated. But it is very difficult to imagine how this will converge into new forms of democratic thinking without a fuller, integrated account of the concomitant assault on the public, evacuation of representative democratic agency.

Approaches that recognize the many ways in which individuals are creatively empowered and emphasize the astonishing array of micropolitics at play at any one time remind us that the politics of recognition and the importance of voice are critical to the felt experience of politics. It can also increase contestability through broadening the range of conflictual content online - a vital political act. But acknowledging this should not give way to a fetishization of notions of plurality and communicative freedom that remain 
encompassed by wider politics of neoliberalism. Democracy conceived of as access to a range of communication and information can only ever take us so far. Pluralism, as a value and set of practices, poses no threat to the neoliberal discourses that can be seen as a powerful and largely successful attempt to reshape the direction of travel of the political for a whole generation, normalizing the individualizing subjectivities that saturate much life and action online, although this may be constantly under challenge. Pluralism does not automatically transcend global capitalism, and communicative freedom is not a given even in the digital age. Our argument here is that Media Studies' core conceptual vocabulary requires disengagement from the risk of passive consent to established neoliberal hegemonies (Gilbert, 2014), as a basic task of critical thought.

As a contribution to this, we have sought to establish that discussions that return to notions of the public sphere, to pluralism and to communicative freedom must take account of the contemporary transformations in global capitalism and representative democratic systems. Unless these consequences are named, claims as to enhancing freedom and supporting democracy remain limited to the 'media side' of an equation that must be critiqued in its totality. This does not mean that we should revert to a politicaleconomic form of determinism, but instead to attend with care to the relations of power between people, state institutions and markets. The rhetoric of liberal democracy that insists we have more choice, more creative control, and that the public sphere is radically expanded must confront how neoliberal hegemony organizes 'states and subjects ... by market rationality' (Brown, 2005) in ways that place stress on established ideological imaginations. The signifiers of democracy have been appropriated even as we continue to trade in them. Much as we mourn their passing, this article proposes an opportunity for Media Studies to give substance to the political democratic project we long for.

\section{Declaration of Conflicting Interests}

The author(s) declared no potential conflicts of interest with respect to the research, authorship, and/or publication of this article.

\section{Funding}

The author(s) received no financial support for the research, authorship and/or publication of this article.

\section{Note}

1. The notion of 'zombie economics' is quoted by Blyth (2013) from John Quiggan's Zombie Economics: How Dead Ideas Still Walk Among Us, which in turn has echoes of Ulrich Beck's broader critique of 'zombie categories' in social science and public discourse, that is, concepts that endure despite their lack of analytical purchase. See Beck and Elizabeth BeckGernsheim (2002). The notion of 'zombie economics' recalls a comparable recent study by Jamie Peck, who presents the gap between the 'pristine clarity of the ideological apparition (of) the free market' and repeated empirical failure as a dialectic that informs a tendency to '... "fail forward," in that their manifest inadequacies have - so far anyway - repeatedly animated further rounds of neoliberal animation'. See Constructions of Neoliberal Rationality. Oxford: Oxford University Press (2011, p. 6, emphasis in original). 


\section{References}

Beck U and Beck-Gernsheim E (2002) Individualization: Institutional Individualism and its Social and Political Consequences. London: SAGE.

Benkler Y (2006) The Wealth of Networks. New Haven, CT: Yale University Press.

Blyth M (2013) Austerity: The History of a Dangerous Idea. Oxford: Oxford University Press.

Brown W (2005) Neoliberalism and the end of liberal democracy. In: Edgework: Critical Essays on Knowledge and Politics. Princeton, NJ: Princeton University Press, pp. 37-59.

Castells M (2009) Communication Power. Oxford: Oxford University Press.

Castells M (2012) Networks of Outrage and Hope. Cambridge: Polity Press.

Crouch C (2004) Post-Democracy. Cambridge: Polity Press.

Crouch C (2011) The Strange Non-Death of Neoliberalism. Cambridge: Polity Press.

Dahlgren P (2009) Media and Political Engagement: Citizens, Communication, Democracy. Cambridge: Cambridge University Press.

De Sousa Santos B (2012) Third letter to the left. Available at: http://hiredknaves.wordpress. com/2012/01/05/occupydemocracy-third-letter-to-the-lefts/ (accessed 18 March 2014).

Dean J (2009) Democracy and Other Neoliberal Fantasies. Durham, NC: Duke University press.

Dorling D (2011) Injustice: Why Social Inequality Persists. Bristol: Policy Press.

Douzinas C (2013) The loss of ERT, the 'Greek BBC' is a cultural calamity. The Guardian, 12 June. Available at: http://www.theguardian.com/commentisfree/2013/jun/12/ert-greek-statebroadcaster-cultural-calamity.

Downey J and Fenton N (2003) Constructing a counter-public sphere. New Media and Society (5)2: 185-202.

Dryzek J (2000) Deliberative Democracy and beyond: Liberals, Critics, Contestations. Oxford: Oxford University Press.

Fossum JE and Schlesinger P (2007) (ed.) The European Union and the Public Sphere: A Communicative Space in the Making? London: Routledge.

Fraser N (1995) From redistribution to recognition? Dilemmas of justice in a 'post-socialist' age. New Left Review I/212, July-August.

Freedman D (2014) The Contradictions of Media Power. London: Bloomsbury.

Gilbert J (2013) What kind of thing is 'neoliberalism'? New Formations 80-81: 7-22.

Gilbert J (2014) Common Ground: Democracy and Collectivity in an Age of Individualism. London: Pluto Press.

Golding P and Middleton S (1982) Images of Welfare: Press and Public Attitudes to Poverty. London: Martin Robertson.

Graeber D (2011) Debt: The First 5000 Years. New York: Melville House.

Gramsci A (1971) Selections from the Prison Notebooks of Antonio Gramsci (ed. and trans. Q Hoare and GN Smith). New York: International Publishers.

Habermas J (1989[1962]) The Structural Transformation of the Public Sphere. Cambridge, MA: The MIT Press.

Hallin D (2009) Neoliberalism, social movements and change in media systems in the late twentieth century. In: Hesmondhalgh D and Toynbee J (eds) The Media and Social Theory. London: Routledge, pp. 43-58.

Harding L (2014) The Snowdon Files. London: Guardian Books.

Hindman M (2008) The Myth of Digital Democracy. Princeton, NJ: Princeton University Press.

Krugman P (2013) How the case for austerity has crumbled. The New York Review of Books, June 6. Available at: http://www.nybooks.com/articles/archives/2013/jun/06/how-case-austerityhas-crumbled/

Lapavitsas C (2012) Crisis in the Eurozone. London: Verso. 
Loader B (ed.) (2007) Young Citizens in the Digital Age: Political Engagement, Young People and New Media. Abingdon: Routledge.

Lodge G and Gottfried G (2011) Worst of Both Worlds: Why First past the Post No Longer Works. London: IPPR.

Lodge G, Gottfried G and Birch S (2013) The political inclusion of young citizens. London: IPPR. Available at: http://eprints.lse.ac.uk/56306/1/Democratic-Audit_Lodge-Gottfried-andBirch_The-Political-Inclusion-of-Young-Citizens.pdf (accessed April 2014).

Lunt P and Livingstone S (2013) 'Media Studies' fascination with the concept of the public sphere: Critical reflections and emerging debates. Media Culture \& Society 35(1): 87-96.

Mair P (2013) Ruling the Void? The Hollowing of Western Democracy. London: Verso.

McKee A (2005) The Public Sphere: An Introduction. Cambridge: Cambridge University Press.

McNally D (2010) Global Slump: The Economics and Politics of Crisis and Resistance. Oakland, CA: PM Press.

Mouffe C (2005) On the Political. London: Routledge.

Nancy J-L (2009) Democracy in the court of reason. Available at: http://aphelis.net/democracycourt-reason-jean-luc-nancy-2009/ (accessed 31 March 2014).

Öktem K (2013) Why Turkey's mainstream media chose to show penguins rather than protests. The Guardian. Available at: http:/www.theguardian.com/commentisfree/2013/jun/09/turkey-mainstream-media-penguins-protests.

Rasmussen T (2013) Internet-based media, Europe and the political public sphere. Media Culture \& Society 35(1): 97104.

Redden J (2011). The mediation of poverty: the news, new media and politics. PhD Thesis, Goldsmiths, University of London, London.

Reinhart CM and Rogoff KS (2010) Growth in a time of debt. NBER Working Paper no. 15639. Available at: http://www.nber.org/papers/w15639.

Schäffer A and Streeck W (2013) (ed.) Politics in the Age of Austerity. Cambridge: Polity Press.

Seymour R (2014) Against Austerity: Class, Ideology and Socialist Strategy. London: Pluto Press.

Streeck W (2011) The crises of democratic capitalism. New Left Review, September-October, p. 71.

Streeck W (2012) Markets and peoples. New Left Review, January-February, p. 73.

Taylor C (1994) The politics of recognition. In: Gutmann A (ed.) Multiculturalism: Examining the Politics of Recognition. Princeton, NJ: Princeton University Press, 25-73.

Tyler I (2013) Revolting Subjects: Social Abjection and Resistance in Neoliberal Britain. London: Zed Books.

Wilkinson RG and Pickett K (2009) The Spirit Level: Why More Equal Societies Almost Always Do Better. London: Allen Lane.

Williams R (1982) Democracy and parliament. Marxism Today, June, pp. 14-21. 